\title{
FIRST RECORD OF MULTIPLE PATERNITY IN THE PYGMY RABBIT (BRACHYLAGUS IDAHOENSIS): EVIDENCE FROM ANALYSIS OF 16 MICROSATELLITE LOCI
}

\author{
Wilfredo Falcón ${ }^{1,3}$, Caren S. Goldberg², Lisette P. Waits², \\ Wendy A. Estes-Zumpf ${ }^{2,4}$, and Janet L. Rachlow ${ }^{2}$
}

\begin{abstract}
Although promiscuity is believed to be common among leporids, little is known about the mating system of free-ranging pygmy rabbits (Brachylagus idahoensis). We used 16 polymorphic microsatellite markers and DNA extracted from tissue samples of 10 rabbits from 2 litters collected in east central Idaho to evaluate paternity. We incorporated maternal genotypes for better resolution and employed an exclusion approach to detect multiple paternity. Our results demonstrated multiple paternity at 6 of the 16 loci tested for each litter. These findings support the expectation that pygmy rabbits have a promiscuous mating system. It has been proposed that multiple paternity could lead to higher effective population sizes and help small populations maintain diversity. Given that pygmy rabbits persist in small and fragmented populations, a promiscuous mating system might be important for maintaining genetic diversity in free-ranging populations and could be advantageous for the captive breeding program.
\end{abstract}

RESumen.-Aunque se cree que la promiscuidad es común entre los lepóridos, se conoce poco sobre el sistema de apareamiento del conejo pigmeo (Brachylagus idahoensis) en condiciones silvestres. Utilizamos 16 marcadores de microsatélites polimórficos y ADN extraído de muestras de tejido de 10 conejos de 2 camadas colectadas en la parte este central de Idaho para evaluar su paternidad. Los genotipos maternos fueron incorporados para lograr una mayor resolución y empleamos un método de exclusión para detectar la paternidad múltiple. Nuestros resultados demuestran paternidad múltiple en 6 de los 16 loci examinados en cada camada. Estos resultados apoyan la suposición de que los conejos pigmeos tienen un sistema de apareamiento promiscuo. Se ha propuesto que la paternidad múltiple podría conducir a tamaños efectivos de la población más grandes y ayudar a que las poblaciones pequeñas mantengan la diversidad. En vista de que el conejo pigmeo persiste en poblaciones pequeñas y fragmentadas, un sistema de apareamiento promiscuo podría ser importante para mantener la diversidad genética en poblaciones silvestres y podría resultar provechoso para el programa de cría en cautiverio.

Lagomorphs exhibit polygamy, which is the predominant mating system for mammalian species (Kleiman 1977). Furthermore, promiscuity, in which both sexes mate with multiple partners, is believed to be a common mating system among leporids (Crowan and Bell 1986), although some behavioral evidence suggests polygyny within the genus Lepus (Flux 1981, Rioja et al. 2008) and even monogamy in the whitesided jackrabbit (Lepus callotis; Best and Henry 1993). Traits consistent with promiscuous mating systems in leporids include limited parental care, overlapping home ranges, and multiple mating (Burton 2002). Although extensively described in birds (Griffith et al. 2002) and documented in all reptiles that have been investigated (Uller and Olsson 2008), multiple paternity has only been documented recently in mammals with promiscuous mating systems (Burton 2002, Kraaijeveld-Smit et al. 2002, Radespiel et al. 2002, Hohoff et al. 2003). Multiple paternity occurs when more than one male fathers a single offspring group (i.e., there is more than one sire for a litter or clutch; Sugg and Chesser 1994). In the genus Sylvilagus, which is considered to be a sister taxon of Brachylagus (Halanych and Robinson 1997, Robinson and Matthee 2005), testis size is suggestive of multiple mating in Sylvilagus floridanus (Stockley 2003); however, genetic evidence has not confirmed the occurrence of multiple paternity in any Sylvilagus species. On the other hand, genetic evidence for multiple paternity was detected in $25 \%$ of the litters tested in the promiscuous snowshoe hare (Lepus americanus; Burton 2002), and also has been documented in the brown hare (Lepus europaeus; Suchentrunk and Hacklaender 2005).

The pygmy rabbit (Brachylagus idahoensis) is the smallest rabbit in North America. It is a sagebrush-dependent species (Artemisia spp.) that uses areas dominated by big sagebrush (A. tridentata) and relatively deep soils (Orr 1940).

${ }^{1}$ University of Puerto Rico at Humacao, Department of Biology, CUH Postal Station 100 Carr. 908, Humacao, PR 00791-4300.

${ }^{2}$ Department of Fish and Wildlife Resources and Center for Research on Invasive Species and Small Populations, University of Idaho, Moscow, ID $83844-1136$. 3Present address: Department of Biology, University of Puerto Rico-Rio Piedras, Box 23360, San Juan, PR 00931-3360. E-mail: wilfredo.falcon@upredu ${ }^{4}$ Present address: Wyoming Natural Diversity Database, University of Wyoming, Laramie, WY 82071. 
The historic range of the pygmy rabbit includes 8 western states: Idaho, Washington, Nevada, Montana, California, Utah, Wyoming, and Oregon (Green and Flinders 1980). In 2003, the U.S. Fish and Wildlife Service listed the distinct population of pygmy rabbits in the Columbia Basin as endangered, and a petition is currently under consideration for federal listing across the species' range (Federal Register 2003, 2008).

The mating behavior and parental care of pygmy rabbits was studied in captivity as part of a captive-breeding program to restore the extirpated Columbia Basin population to their historic range in Washington (Elias et al. 2006). Mating behavior consisted of several chases and brief copulations. Unlike females of other lagomorph species in North America, female pygmy rabbits dug natal burrows, usually separated from their residential burrow systems, and covered the entrance of the burrows after the kits were born. In the wild, female pygmy rabbits dug natal burrows at considerable distances from their residential burrow systems (Rachlow et al. 2005).

Few field studies have reported observations of mating behavior of free-ranging pygmy rabbits (Janson 1940, Wilde 1978, Fisher 1979), and no studies have tested for multiple paternity. In captivity, male pygmy rabbits exhibited no parental care, and females provided relatively little care (nursing 1-2 times per day), like many other leporids (Elias et al. 2006, Bautista et al. 2008). In the wild, male pygmy rabbits tend to have larger home ranges and core areas, especially during the breeding season, and more dispersed burrow systems than females, possibly due to mate-search behavior (Burak 2006, Crawford 2008, Sanchez and Rachlow 2008). Switching among burrow systems is a common behavior for both sexes. Also, the overlap of home ranges between individuals of both sexes is common (Burak 2006, Sanchez and Rachlow 2008). Pygmy rabbits breed from February to July, producing up to 3 litters per year with a per litter average of 6 young (Wilde 1978, Elias et al. 2006). These ecological and behavioral characteristics create the opportunity for multiple paternity events in the pygmy rabbit.

To assess whether multiple paternity occurs in B. idahoensis, we used 16 polymorphic microsatellite markers and DNA extracted from ear tissue samples obtained from 2 litters collected at 2 sites in east central Idaho. The study sites (Cedar Gulch and Rocky Canyon) are located about $6 \mathrm{~km}$ apart in the Lemhi Valley along the
Idaho-Montana border. Both sites are dominated by sagebrush vegetation and mounded microtopography. For a detailed description of the sites, see Estes-Zumpf and Rachlow (2009). This analysis represents the first investigation of paternity in free-ranging pygmy rabbits.

We evaluated paternity for 10 rabbits from 2 litters. One litter consisted of 4 near-term kits collected from the carcass of a female at the Cedar Gulch (CG) site. The second litter consisted of 6 kits sampled from a natal burrow found at the Rocky Canyon (RC) site. Because the mother of the second litter was unknown, we also analyzed DNA samples for parentage from potential mothers in the vicinity of the natal burrow. These adult females were trapped during concurrent studies on space use and movement patterns by pygmy rabbits (Sanchez and Rachlow 2008, Estes-Zumpf 2008). All adult females captured within $400 \mathrm{~m}$ of the natal burrow were evaluated as potential mothers. This distance was almost double the mean width of female home ranges during the breeding season $(250 \mathrm{~m}$; Sanchez and Rachlow 2008).

We extracted DNA using the Qiagen tissue kit, following the Qiagen tissue protocol (Qiagen Inc., Valencia, CA) at the Laboratory for Conservation and Ecological Genetics (University of Idaho, Moscow, ID). Tissue samples were frozen in ethanol prior to DNA extraction. See EstesZumpf et al. (2010) for a detailed protocol.

We used the polymerase chain reaction (PCR) to amplify 16 microsatellite loci: 9 microsatellites developed for pygmy rabbits (A2, A10, A121, A124, A133, D103, D118, D121, and D126; Estes-Zumpf et al. 2008) and 7 developed for the European rabbit (Oryctolagus cuniculus; Sol08, Sol30, Sat05, Sat07, Sat08, Sat12, and Sol44; Rico et al. 1994, Mougel et al. 1997, Surridge et al. 1997, Warheit 2001). We multiplexed the microsatellite markers following the PCR conditions established by Estes-Zumpf et al. (2008) and Estes-Zumpf (2008, appendixes G and H). The microsatellite genotypes were visualized with an Applied Biosystems 3130xl sequencer (Applied Biosystems, Foster City, CA), and alleles were scored using GeneMapper 3.7 (Applied Biosystems). We conducted a minimum of 2 PCRs per locus per sample and required that each allele was observed $\geq 2$ times before finalizing a genotype. In a few cases, we encountered disagreements among PCRs due to allelic dropouts or false alleles, and genotypes were replicated 3-5 times until an accurate consensus 
TABLE 1. Microsatellite analysis of multiple paternity in 2 litters of pygmy rabbits collected in east central Idaho. This table shows the total number of alleles and the number of paternal alleles per litter per locus. Bolded, italicized numbers indicate evidence of multiple paternity. $\mathrm{CG}=$ Cedar Gulch litter, and RC = Rocky Canyon litter.

\begin{tabular}{lcccc}
\hline Locus & $\begin{array}{c}\text { Alleles } \\
\text { per litter } \\
(\mathrm{CG})\end{array}$ & $\begin{array}{c}\text { Paternal } \\
\text { alleles } \\
(\mathrm{CG})\end{array}$ & $\begin{array}{c}\text { Alleles } \\
\text { per litter } \\
(\mathrm{RC})\end{array}$ & $\begin{array}{c}\text { Paternal } \\
\text { alleles } \\
(\mathrm{RC})\end{array}$ \\
\hline A2 & 5 & 3 & 4 & 2 \\
A133 & 3 & 2 & 4 & 3 \\
A121 & 4 & 2 & 4 & 2 \\
D103 & 1 & 1 & 3 & 2 \\
Sat05 & 2 & 2 & 4 & 4 \\
A10 & 4 & 3 & 3 & 3 \\
Sol08 & 4 & 2 & 3 & 3 \\
Sat08 & 3 & 3 & 4 & 2 \\
D126 & 1 & 1 & 3 & 2 \\
Sol44 & 5 & 3 & 4 & 3 \\
Sol30 & 4 & 3 & 4 & 2 \\
D118 & 2 & 2 & 3 & 2 \\
Sat12 & 4 & 3 & 2 & 1 \\
Sat07 & 1 & 1 & 3 & 2 \\
D121 & 2 & 2 & 4 & 3 \\
A124 & 4 & 2 & 3 & 2 \\
\hline
\end{tabular}

genotype could be determined. We estimated genetic diversity and the probability of parental exclusion using program CERVUS v.3.0.3 (Kalinowski et al. 2007). To assess parentage from potential mothers for the RC litter, we evaluated the alleles present in the litter and the potential mothers by applying an exclusion approach (Jones and Ardren 2003). Following basic Mendelian rules of inheritance, we excluded potential mothers with allelic disagreements. These loci were highly polymorphic, with an average of 7.85 alleles per locus and an expected heterozygosity of 0.758 . The probability of parental exclusion with one parent known was 0.99999 and the probability of exclusion when both parents were unknown was 0.999726 , indicating that we had high power to determine parentage and detect multiple paternity.

To test for evidence of multiple paternity, we evaluated the number of alleles per locus in each litter. This method yields 2 possible results: (1) evidence of 5 or more alleles at one or more loci across the offspring group (littermates) would indicate multiple paternity (alternative hypothesis in a null model), or (2) 1-4 alleles per locus per litter fails to provide evidence of multiple paternity (null hypothesis). When we included the maternal genotypes, we had greater resolution; if the females were homozygous at a locus, we expected to detect a maximum of 3 alleles per locus for each litter if there was a single sire.
More than 3 alleles provided evidence of multiple paternity.

We assessed genotypes for 7 adult females that were trapped within $400 \mathrm{~m}$ of the natal burrow for the litter sampled at the RC site. None of the females matched the litter across all loci; however, one female was consistent at all loci except for D118. At that locus, the mismatch consisted of a 2 base-pair disagreement with 2 kits. The probability of exclusion for females using this set of loci was 0.999 , indicating that the probability of this female not being the mother was $<0.001$. Thus, we concluded that this female was the mother. D118 is a dinucleotide locus for which we suspect a mutation by replication slippage, which is characterized by the addition or deletion of repeats in the microsatellite (reviewed in Ellegreen 2000).

Our results demonstrated multiple paternity for both litters tested. Evidence of multiple paternity was detected at loci A2, A10, Sat08, Sol44, Sol30, and Sat12 for the CG litter, and loci A133, Sat05, A10, Sol08, Sol44, and D121 for the RC litter (Table 1). For both litters, knowledge of the maternal genotype greatly increased our ability to detect multiple paternity, and in fact, we could not detect multiple paternity for the RC litter without this information (Table 1). For the loci with evidence of multiple paternity, we found 3 and 4 paternal alleles in the CG and RC litters, respectively, which indicates a minimum of 2 sires per litter.

This study is the first to evaluate patterns of paternity for pygmy rabbits and the first to document multiple paternity in this species. Our findings support the expectation that pygmy rabbits, like other lagomorphs, have a promiscuous mating system. Promiscuity has been linked with multiple paternity in other species, including the meadow vole (Microtus pennsylvanicus; Berteaux et al. 1999), agile antechinus (Antechinus agilis; Kraaijeveld-Smit et al. 2002), yellowtoothed cavy (Galea musteloides; Hohoff et al. 2003), gray mouse lemur (Microcebus murinus; Radespiel et al. 2002), and the snowshoe hare (Lepus americanus; Burton 2002). Our results are also consistent with traits associated with multiple paternity in free-ranging populations. Due to our small sample size, we could not evaluate the prevalence of multiple paternity in our study population. However, we documented multiple paternity in both litters that we tested, which indicates that this reproductive pattern might be relatively common within this species. 
Multiple paternity has several ecological and evolutionary implications. Populations that exhibit multiple paternity tend to have larger effective population sizes (Sugg and Chesser 1994), a reduction of inbreeding (Stockley et al. 1993), and a reduction in the costs of reproductive failure resulting from genetic incompatibility (Stockley 2003). Given that pygmy rabbits currently persist in small and often fragmented populations (Rachlow and Svancara 2006, Larrucea and Brussard 2008) and might have done so historically (Grayson 1987), these traits might be important for maintaining genetic diversity within free-ranging populations. Such traits could also assist in meeting the goals of the captive breeding program for the endangered Columbia Basin population.

This study was supported by the National Science Foundation (REU grant ID 0755160) and the Center for Research on Invasive Species and Small Populations at the University of Idaho. We collected samples during fieldwork supported by the Bureau of Land Management, Idaho Department of Fish and Game, and USDA Forest Service. We thank the Leadore Ranger District staff for logistic support and Mary Sterling for assistance with lab work.

\section{Literature Cited}

Bautista, A., M. Martínez-Gómez, And R. Hudson. 2008. Mother-young and within-litter relations in the European rabbit Oryctolagus cuniculus. In: P.C. Alves, N. Ferrand, and K. Hackländer, editors, Lagomorph biology: evolution, ecology, and conservation. Springer, Berlin.

Berteaux, D., F. BÊty, E. Rengifo, and J. Bergeon. 1999. Multiple paternity in meadow voles (Microtus pennsylvanicus): investigating the role of the female. Behavioral Ecology and Sociobiology 45:283-291.

Best, T.L., And T.H. Henry. 1993. Lepus callotis. Mammalian Species 442:1-6.

BuRAK, G.S. 2006. Home ranges, movements, and multiscale habitat use of pygmy rabbits (Brachylagus idahoensis) in southwestern Idaho. Master's thesis, Boise State University, Boise, ID.

Burton, C. 2002. Microsatellite analysis of multiple paternity and male reproductive success in the promiscuous snowshoe hare. Canadian Journal of Zoology 80: 1948-1956.

Crawford, J.A. 2008. Survival, movements, and habitat selection of pygmy rabbits (Brachylagus idahoensis) on the Great Basin of southwestern Oregon and northwestern Nevada. Master's thesis, Oregon State University, Corvallis, OR.

Crowan, D.P., AND D.J. BELL. 1986. Leporid social behavior and social organization. Mammal Review 16:169-179.

Elias, B., L.A. Shipley, R. Sayler, and R. Lamson. 2006. Mating and parental care in captive pygmy rabbits. Journal of Mammalogy 87:921-928.
Ellegreen, H. 2000. Microsatellite mutations in the germ line: implications for evolutionary inference. Trends in Genetics 16:551-558.

Estes-ZumpF, W.A. 2008. Dispersal and gene flow among pygmy rabbit (Brachylagus idahoensis) populations in Idaho and southwestern Montana. Doctoral dissertation, Department of Wildlife Resources, University of Idaho, Moscow, ID.

Estes-Zumpf, W.A., AND J.L. RaChlow. 2009. Natal dispersal by pygmy rabbits (Brachylagus idahoensis). Journal of Mammalogy 90:363-372.

Estes-ZumpF, W.A., J.L. RACHLOW, AND L.P. WAITS. 2008. Ten polymorphic microsatellite markers for the pygmy rabbit (Brachylagus idahoensis). Molecular Ecology Resources 8:360-362.

Estes-Zumpf, W.A., J.L. Rachlow, L.P. Waits, and K.I. WARHEIT. 2010. Dispersal, gene flow, and population genetic structure in the pygmy rabbit (Brachylagus idahoensis). Journal of Mammalogy 91:208-219.

Federal Register. 2003 [March 5]. Endangered and threatened wildlife and plants; final rule to list the Columbia Basin Distinct population segment of the pygmy rabbit (Brachylagus idahoensis) as endangered. Federal Register 68:10388-10409.

Federal Register. 2008 [January 8]. Endangered and threatened wildlife and plants; 90-day finding on a petition to list the pygmy rabbit (Brachylagus idahoensis) as threatened or endangered. Federal Register 73:1312-1313.

FisheR, J.S. 1979. Reproduction in the pygmy rabbit in southeastern Idaho. Master's thesis, Idaho State University, Pocatello, ID.

FLuX, J.E.C. 1981. Reproductive strategies in the genus Lepus. Pages 155-174 in K. Myers and C.D. MacInnes, editors, Proceedings of the World Lagomorph Conference. University of Guelph, Guelph, Ontario, Canada.

Grayson, D.K. 1987. The biogeographic history of small mammals in the Great Basin: observations on the last 20,000 years. Journal of Mammalogy 68:359-375.

GreEN, J.S., AND J.T. Flinders. 1980. Brachylagus idahoensis. Mammalian Species 125:1-4.

Griffith, S.C., I.P.F. OWens, and K.A. Thuman. 2002 Extra pair paternity in birds: a review of interspecific variation and adaptive function. Molecular Ecology 11:2195-2212.

HalanyCh, K.M., and T.J. Robinson. 1997. Phylogenetic relationships of cottontails (Sylvilagus, Lagomorpha): congruence of $12 \mathrm{~S} \mathrm{rDNA}$ and cytogenetic data. Molecular Phylogenetics and Evolution 7:294-302.

Hohoff, C., K. Franzen, And N. Sachser. 2003. Female choice in a promiscuous wild guinea pig, the yellowtoothed cavy (Galea musteloides). Behavioral Ecology and Sociobiology 53:341-349.

JANSON, R. 1940. Distribution and life history studies of the Idaho pygmy rabbit, Sylvilagus idahoensis (Merriam), in Utah and southeastern Idaho. Bachelor's thesis, Utah State Agricultural College, Logan, UT.

Jones, A.G., AND W.R. ARdren. 2003. Methods of parentage analysis in natural populations. Molecular Ecology 12: 2511-2523.

Kalinowski, S.T., M.L. TAPER, And T.C. MarshaLl. 2007. Revising how the computer program CERVUS accommodates genotyping error increases success in paternity assignment. Molecular Ecology 16: 1099-1106.

Kleiman, D.G. 1977. Monogamy in mammals. Quarterly Review of Biology 52:39-68. 
KraAjeVEld-Smit, FJ.L., S.J. WaRD, AND P.D. TEMPLE-Smit 2002. Multiple paternity in a field population of a small carnivorous marsupial, the agile antechinus, Antechinus agilis. Behavioral Ecology and Sociobiology 52:84-91.

LARRUCEA, E.S., AND P.F. BRUSSARD. 2008. Habitat selection and current distribution of the pygmy rabbit in $\mathrm{Ne}$ vada and California, USA. Journal of Mammalogy 89: 691-699.

Mougel, F., J.C. Mounolou, and M. Monnerot. 1997. Nine polymorphic microsatellite loci in the rabbit, Oryctolagus cuniculus. Animal Genetics 28:58-59.

ORR, R.T. 1940. The rabbits of California. Occasional Papers of the California Academy of Sciences 19:1-22.

RaChlow, J.L., D.M. SÁnCheZ, and W.A. Estes-ZumpF. 2005. Natal burrows and nests of free-ranging pygmy rabbits (Brachylagus idahoensis). Western North American Naturalist 65:136-139.

Rachlow, J.L., AND L.K. SvanCara. 2006. Prioritizing habitat for surveys of a rare mammal: a modeling approach applied to pygmy rabbits. Journal of Mammalogy 87:827-833.

Radespiel, U., V. Dal Secco, C. Drögemüller, P. Braune, E. Labes, And E. Zimmermann. 2002. Sexual selection, multiple mating and paternity in grey mouse lemurs, Microcebus murinus. Animal Behavior 63:259-268.

Rico, C., I. Rico, N. Webb, S. Smith, D. Bell, and G. HEwITT. 1994. Four polymorphic microsatellite loci for the European wild rabbit, Oryctolagus cuniculus Animal Genetics 25:367.

Rioja, T., C. Lorenzo, E. Naranjo, L. Scott, and A. CarRILLO-REYES. 2008. Polygynous mating behavior in the endangered Tehuantepec jackrabbit (Lepus flavigularis). Western North American Naturalist 68 343-349.

Robinson, T.J., and C.A. Matthee. 2005. Phylogeny and evolutionary origins of the Leporidae: a review of cyto- genetics, molecular analyses and a supermatrix analysis. Mammal Review 35:231-247.

SANCHEZ, D.M., AND J.L. RaChlow. 2008. Spatio-temporal factors shaping diurnal space use by pygmy rabbits. Journal of Wildlife Management 72:1304-1310.

STOCKLEY, P. 2003. Female multiple mating behavior, early reproductive failure and litter size variation in mammals. Proceedings: The Royal Society 270:271-278.

Stockley, P., J.B. Searle, D.W. Macdonald, and C.S. JoNEs. 1993. Female multiple mating behaviour in the common shrew as a strategy to reduce inbreeding. Proceedings of the Royal Society of London Series B 254:173-179.

Suchentrunk, F., AND K. Hacklaender. 2005. Maternal and fetal microsatellite genotypes reveal multiple paternity in a brown hare (Lepus europaeus) population. Mammalian Biology 70 (Supplement):39.

SugG, D.W., AND R.K. Chesser. 1994. Effective population sizes with multiple paternity. Journal of Genetics 137: 1147-1155.

Surridge, A.B., D.J. Bell, C. Rico, and G.M. HewitT. 1997. Polymorphic microsatellite loci in the European rabbit (Oryctolagus cuniculus). Animal Genetics 28: 302-305.

Uller, T., AND M. Olsson. 2008. Multiple paternity in reptiles: patterns and processes. Molecular Ecology 17: 2566-2580.

WARHEIT, K.J. 2001. Genetic diversity and population differentiation of pygmy rabbits (Brachylagus idahoensis). Washington Department of Fish and Wildlife, Wildlife Research Division, Olympia, WA.

WILDE, D.B. 1978. A population analysis of the pygmy rabbit (Sylvilagus idahoensis) on the INEL site. Doctoral dissertation, Idaho State University, Pocatello, ID.

Received 4 June 2010 Accepted 6 January 2011 